\title{
Comment on "Critics of the Judicial Committee: The New Orthodoxy and an Alternative Explanation",
}

\author{
ALAN C. CAIRNS University of British Columbia
}

The 1982 Charter gives the contemporary Supreme Court enhanced responsibilities in the overall Canadian constitutional system. These novel responsibilities require a jurisprudence appropriate to the new relations between courts and legislatures for which our past has ill-prepared us. In addition to the Charter and the host of citizen-state relations which are thus placed on the Supreme Court agenda, the 1982 Constitution Act, s. 52(1), establishes the supremacy of the constitution, which further underlines the growing significance of the judicial branch in our constitutional future. Are judges to be the midwives of constitutional evolution, seeking to adapt the constitution as an instrument of government to emerging conditions, or are they largely to eschew such a role by employing varying strategies and philosophies of self-control, such as adhering as closely as possible to a more technical task definition, deferring wherever possible to legislatures, resisting the lure of judicial creativity as inappropriate to their appointed status, and throwing the burden of constitutional adaptation on other more overtly political institutions of government?

In answering these difficult questions, which involve assessments of judicial capacity and the political theory of a representative federal democracy now possessed of a Charter of Rights, one strategy is to explore the past, to search for answers or negative lessons from the experience of our predecessors. The expansion of the contemporary judicial role thus reopens past jurisprudential controversies as history is viewed through new lenses. One impressive example of this rethinking is the provocative article by Professor Vaughan, to which this note is a response. His task was to assess the analytical basis of support for the Judicial Committee's overall interpretation of the BNA Act by G. P. Browne, Peter Russell and myself.

It is worth noting that the Browne-Russell-Cairns position of which Vaughan is critical is itself a departure from the conventional criticism of

Canadian Journal of Political Science / Revue canadienne de science politique, XIX:3 (September/ septembre 1986). Printed in Canada / Imprimé au Canada 
the Judicial Committee which became dominant in the legal and nationalist circles of English Canada in the period leading up to the 1949 abolition of appeals. Indirectly, therefore, Vaughan is returning to a previous orthodoxy. To the extent that he succeeds in his task, the performance of the Judicial Committee will receive low marks ${ }^{1}$ and those who formerly criticized it will have their reputations invigorated. It is also relevant to his task that Vaughan views his "opponents" as provincialists. Browne is described as fearing "a dominant federal legislative power" and as adhering to a "simplistic view" of federalism, based on Wheare, which is "incompatible" with "the conception of federalism embodied in the BNA Act." 2 Russell is one of "the most inveterate defenders of provincial autonomy, ${ }^{\prime 3}$ and I am alleged to be a supporter of the Judicial Committee because I am an exponent of province-building, and the Judicial Committee's contribution to the evolution of Canadian federalism was congruent with my preferences. ${ }^{4}$ The debate, therefore, is partly cast in centralist-provincialist terms with Vaughan donning the mantle of John A. Macdonald.

Vaughan has little difficulty in indicating that the three of us provide different, if partially overlapping, rationales for our evaluation of the performance of the Judicial Committee. In particular, G. P. Browne elaborated a highly technical defence of the law lords based on a three-compartment interpretation of sections 91 and 92 . My position is correctly viewed as more sociological than Browne's, and as opposed to confining the debate to the terms of the 1867 Act or to the intentions of the Fathers. Peter Russell, who is separately responding to Vaughan's article, is described as drawing on both Browne and Cairns.

In my 1971 article I did not, as Vaughan claims, seek to silence the critics of the Judicial Committee "once and for all," and I do not identify with a new "orthodoxy ... [which] ... rejects impatiently criticisms of the law lords and what they wrought." ${ }^{5}$ More generally, I take for

I There is, however, an ambiguity in his position which, while generally critical of Judicial Committee performance, contains the odd statement, perhaps only rhetorical: "However reasonable the course taken by the Judicial Committee of the Privy Council now in retrospect appears..." (Frederick Vaughan, "Critics of the Judicial Committee: The New Orthodoxy and an Alternative Explanation," this JoURnal 19 [1986], 495-519, at 519).

2 Vaughan, "Critics of the Judicial Committee," 500.

3 Ibid., 506.

4 Ibid., 501-02, 503. In general, I do not accept the label provincialist and I deny that my attitude to the Judicial Committee is a product of a provincial perspective. In the article which I co-authored with Ed Black ("'A Different Perspective on Canadian Federalism," Canadian Public Administration 9 [1966], 43), concern was expressed over several possible negative consequences of province-building. Evidence is not lacking in my other writings of a centralist, nation-building perspective.

5 Vaughan, "Critics of the Judicial Committee," 495. For example, I am impressed with and sympathetic to the recent argument of Gordon Bale, which is highly critical of the Judicial Committee decisions in the Manitoba School cases in the 1890s ("Law, 
granted that it is the fate of our always limited understandings to be modified and surpassed by subsequent scholarship. So I am pleased that Vaughan has decided to "re-open the controversy," "which is not to say that I am in agreement with his basic position.

Initially, it is necessary to deal with Vaughan's alternative explanation of "why the Judicial Committee emasculated the centralizing terms of the British North America Act." "His thesis is that the law lords viewed their function as "essentially political," which they translated into "giving effect to a conception of federalism which was clearly counter to that contained in the BNA Act." "The Judicial Committee saw itself as part of the "legislative process" with the task of making up for the " 'negligence and incapacity' of the Imperial Parliament and the Canadian framers in 1867. "9 This is an alternative to Browne's technical three-compartment explanation of what drove the law lords in a provincialist direction. However, it is clear that both Russell and I are in agreement with Vaughan that the Judicial Committee injected a decentralizing impulse into the centralized federalism with which Canada began its existence. ${ }^{10}$ The "alternative" in his explanation thus presumably refers to the political or legislative definition of their task which he asserts was held by the law lords.

However, section 4 ("Towards an Alternative Explanation"), in which this position is elaborated, is less than convincing on why an essentially political view of their task drove the Judicial Committee in a provincialist direction. ${ }^{11}$ Vaughan accepts recent scholarship by Stephen Wexler and Jonathon Robinson as helpful in explaining Haldane's position, but he denies that the pro-provincial behaviour of other law lords was a byproduct of Haldane's beliefs or influence. In fact, he has no answer to the question of why the Privy Council had a particular conception of federalism that led them to throw their weight on the side of the provinces. His unwillingness to look at developments in Canadian society works against his acceptance of one plausible explanation-that they thought such a conception was appropriate to the realities of the country whose constitution they were interpreting.

Politics and the Manitoba School Question: Supreme Court and Privy Council," Canadian Bar Review 63 [1985], 462-518).

6 Vaughan, "Critics of the Judicial Committee," 495.

7 Ibid., 512 .

8 Ibid., 514.

9 Ibid., 519.

10 Peter H. Russell (ed.), Leading Constitutional Decisions (3rd ed.: Ottawa: Carleton University Press, 1982), 8, 12: Alan C. Cairns, "The Judicial Committee and its Critics," this Journal. 4 (1971), 323.

11 Somewhat paradoxically, at one point Vaughan reverses the sequence and suggests that "why they viewed... [their] function... as essentially political" was because they were "intent on giving effect to a conception of federalism which was clearly counter to that contained in the BNA Act" (Vaughan, "Critics of the Judicial Committee," S14: italics added). 
In any event, Vaughan's alternative explanation of why the Judicial Committee did what it did is not a response to the question which concerned me-the adequacy of the criteria by which Canadian scholars, politicians and others had judged the overall tendency of its decisions. The major purpose of my article was to examine the Pavlovian-type criticisms of the Judicial Committee which had become a thought-stifling conventional wisdom in English-Canadian commentary. I documented almost ad nauseam the profound divide between the two main orientations found among the critics, which I labelled fundamentalist and constitutionalist, noted that they contradicted each other, and argued that neither was up to the task of providing convincing normative criteria to evaluate judicial performance. ${ }^{12}$

My major concern ${ }^{13}$ in much of the remainder of this comment is with the criteria to evaluate the judicial role in constitutional interpretation provided by Vaughan. Vaughan's position on how a final appeal court should perform its task of constitutional interpretation is scattered through his article. I risk doing an injustice to his thought by providing my interpretation of his answer to a question which he did not directly address. I interpret him as supporting a version of that espoused by the O'Connor Report in 193914 - that both the terms of the BNA Act and the intentions which it reflected were clearly centralist, and that judges should simply give effect to those terms for they reflect a superior wisdom with which later generations, especially judges, should not tamper.

Vaughan's position may be reconstructed as follows:

(1) The BNA Act clearly established a highly centralized federal system. ${ }^{15}$

(2) The debates in the legislatures of the four Atlantic colonies, as

12 Cairns, "The Judicial Committee and its Critics," 302-12, 332-44.

13 Several small points may be relegated to a footnote. I disagree with Vaughan's assertion that my view of the Fathers or their work "is highly negative" (502). To say that they "lacked the gift of foresight" is not a criticism but a statement of the human condition. I did not say that they were "the victims of a "completely static society,", but that a fundamentalist approach to their creation was only plausible for "a completely static society, in which the original settlement was perfectly suited to existing social values and needs" (Cairns, "The Judicial Committee and its Critics," 335) and went on to make the point, that $I$ have not heard denied, that post-confederation Canada was not a static society. I did not dismiss them as "a small body of men in the 1860 s," but simply noted that is what they were. I do not worship the Fathers and their creation in every detail. Who does? I respect them and it.

14 Report Pursuant to Resolution of the Senate to the Honourable the Speaker by the Parliamentary Counsel Relating to the Enactment of the British North America Act, 1867. any lack of consonance between its terms and judicial construction of them and cognate matters (Ottawa, 1939).

15 Vaughan, "Critics of the Judicial Committee," 500-01. 
well as in the United Province of Canada, confirm that the federalism constructed was seen as, and was intended to be, highly centralized. ${ }^{16}$

(3) The adoption of a centralist federalism was based on a particular understanding of the appropriate relation of the institutions of government to society, with which Vaughan is in agreement. A centralist federalism was constructed not in ignorance of centrifugal forces, but as a deliberate attempt to control them. In Vaughan's words:

Our founders ... attempted to erect a federal system that would minimize the centrifugal political forces by locating the cementing force in the legislative division of powers. The federal or national legislature was given the dominant and residuary powers. When the Judicial Committee frustrated the development of the original federal dominance, it had the effect of ungluing the unique federal system designed by the Fathers of Confederation. As a result, we are left with a federal system that is seriously lacking an institutional body by which to bind the several provinces at the centre so as to ensure the continued existence of Canada as one nation. ${ }^{17}$

(4) Given Vaughan's attribution of enduring wisdom to the constitutional design of the Fathers, the task of judicial interpretation was to protect that centralist structure by a literal, fundamentalist approach to the Act which embodies the intentions of the Fathers. In particular, Vaughan is hostile to a sociological jurisprudence which stresses the need to respond to provincially based diversities. Such an approach is a perversion of the originally understood relationship between the centre and the provinces. Equally, he opposes, for the same reason, the injection of a Wheare-type definition of federalism into the jurisprudence of the very different centralized Canadian federalism. ${ }^{18}$

(5) Implicit in the Vaughan position is the assumption that the Judicial Committee and the Canadian courts subordinate to it could have sustained a highly centralized federal system simply by a faithful interpretation of the BNA Act. Their failure to do so made the Canadian system more authentically federal, and thus made the law lords "the real fathers of Canadian confederation." 19

Vaughan's basic constitutional philosophy is summed up in (3), although his abbreviated presentation may lend itself to misinterpretation. Exactly how a dominant national legislature would bind the several provinces at the centre is unclear. In more than a century of federalism we have seen several periods in which a strong

16 lbid., 511-12.

17 Ibid., 505. In light of the above I am unclear why Vaughan concludes that in addition to strengthening the provinces. the Judicial Committee also " preserv[ed] the integrity of the federal government and Parliament" (ibid.. 519). This sounds suspiciously like praise.

$18^{\circ}$ Ibid., 500.

19 Ibid., 519. 
centre could not maintain itself, and precipitated counter-tendencies to its own brief hegemonies.

Vaughan is not a fan of federalism. He refers positively to John A. Macdonald's "thoughts on the inherent weakness of the federal form of government," 20 and he minimizes the federal element in the confederation settlement. In remarkably strong language he asserts that the "confederation plan clearly contained a deceptive constitutionalism by giving the impression that the new constitution embodied the federal principle in an effective manner. ${ }^{21} \mathrm{He}$ approvingly quotes Christopher Dunkin, who "revealed that the principle of centralization contained in the plan destroyed any semblance of federalism." ${ }^{22}$ This "centralized constitutionalism" was to be sustained by "authoritative judicial determination," to which end early efforts were directed to the establishment of a Supreme Court cognizant of "the hopes and aspirations of the new nation." 23

Limitations of space preclude disentangling the multiple issues involved in the above position, in contrast to which the late Donald Creighton looks like a rampant provincialist. Silver's recent volume indicates clearly that in Quebec the confederation scheme was not seen in the way it is portrayed by Vaughan. In Quebec, "Confederationist propaganda ... underlined the Quebec-centredness of French Canada's approach to Confederation, and the degree to which French Quebec's separateness and autonomy were central to French-Canadian acceptance of the new régime." ${ }^{24}$

Of more serious import than differences of historical interpretation, to found the judicial task on obeisance to a deceptive constitutionalism is unlikely to produce either a wholesome jurisprudence or a functionally necessary respect for the integrity of the judicial process. Presumably the original deception reflected the belief that clarity would have weakened the chances of getting agreement on the terms of confederation. Was the judicial task to continue with the deception, assuming of course that judges could clearly see through it, or was the unmasking to take place on the bench? ${ }^{25}$ Neither role would seem capable of eliciting much judicial enthusiasm.

20 Ibid., 504.

21 Ibid., 510.

22 Ibid., 510-11.

23 Ibid., 511.

24 A. I. Silver, The French-Canadian Idea of Confederation 1864-1900 (Toronto: University of Toronto Press, 1982), 50.

25 There is some tension, if not contradiction, between the argument that on the one hand the confederation plan embodied a "deceptive constitutionalism," which presumably provided a spurious appearance of federalism, and the thesis stated elsewhere that "The BNA Act is not contradictory... [but $]$... crudely centralist... [reflecting] ... the conscious effort of the framers of the Act" (Vaughan, "Critics of the Judicial Committee," 510, 513). 
It is symptomatic of Vaughan's fundamentalist position that neither society nor post-confederation history enters into his analysis. Thus he avoids having to discuss whether post-confederation developments might have justified a departure, to which courts could properly have contributed, from the centralist intentions of the founders. He displays no apparent sympathy with the idea of a living constitution. By inference, the steel frame of a centralized constitutionalism could have both survived and tamed subsequent centrifugal pressures as the four-province Canada of 1867 expanded to ten provinces and as the country moved through eras of war and peace, of economic growth and stagnation. Vaughan does not, of course, explicitly support such a thesis, but the logic of his argument requires that he be able to do so. It is not an easy task which he has left undone. There is considerable academic support for the proposition, to which I subscribe, that the federalism of 1867 was too centralist for the underlying regionalism of the country, to which it subsequently responded. ${ }^{26}$

I am equally unable to support a thesis which attaches primary causal significance to judicial decisions for the subsequent evolution of Canadian federalism away from its 1867 beginnings. Judicial decisions are the product of judge and company, and there was a goodly company that supported the decentralizing impulse that the Judicial Committee injected into Canadian federalism. ${ }^{27}$ It is also undeniable, as previously argued, ${ }^{28}$ that various instruments of centralization fell into disuse for reasons unrelated to judicial pronouncements. It was not Watson or Haldane who rendered the disallowance power obsolete, or caused section 94 to be a dead letter. Further, it was not only judicial interpretation, but the accidents of history that made so many of the provincial responsibilities far more significant than they were originally intended to be.

The Vaughan position on the capacity of a faithful court to preserve the reality of a centralized federalism independently of developments external to the constitution, and conversely his affixing of the primary responsibility for the post-1867 decentralization of Canadian federalism on the Judicial Committee, both reflect a primacy accorded to judicial power, and, relatedly, an attribution of capacity to institutions to shape society which is striking, even in an era in which political science is Bringing the State Back $\operatorname{In} .^{29}$ My general sympathy with the perspective that institutions matter and that the state has significant moulding power falls short of the position I detect in the Vaughan analysis. This means

26 See Cairns, "The Judicial Committee and its Critics." 323, n. 99 for extensive references and quotations.

27 Ibid., 319-20.

28 Ibid., 322.

29 Peter B. Evans, Dietrich Rueschemeyer and Theda Skocpol (eds.), Bringing the Stute Back In (Cambridge: Cambridge University Press. 1985). 
that ultimately the differences in our evaluations of the Judicial Committee rest on prior differences of understanding of the way society works. I do not think that the role which Vaughan would have had the Judicial Committee perform would have been sufficient to "bind the several provinces at the centre so as to ensure the continued existence of Canada as one nation" 30 of the kind he seems to have in mind. Accordingly, I applaud rather than denigrate a court which can roll with the punches and respond to insistent pressures while preserving the basic constitutional structure of the polity.

If I infer Vaughan's position correctly, as hewing closely to the fundamentalist posture in jurisprudential discourse, I simply extend to his presentation the criticisms I applied to an earlier generation of fundamentalists in my 1971 article. My appraisal of the fundamentalist position, which is too lengthy to be repeated here,$^{31}$ is summed up in the critique by Evan Gray of the fundamentalist posture of the O'Connor Report, which is based on "the pretension... that by a miracle of understanding and foresight, the Canadian Fathers of Confederation provided in 1867 a constitution suitable to any future." 32

My own position is close to that of K. N. Llewellyn:

there is no quarrel to be had with judges merely because they disregard or twist Documentary language, or "interpret" it to the despair of original intent, in the service of what those judges conceive to be the inherent nature of our institutions. To my mind, such action is their duty. To my mind, the judge who builds his decision to conform with his conception of what our institutions must be if we are to continue, roots in the deepest wisdom. ${ }^{33}$

Two additional points in conclusion:

(1) Although the opening statement of purpose and the concluding retrospective statement of purpose in my article employ different language and perhaps reflect different shadings of emphasis, I do not agree with Vaughan that my vagueness "betrays considerable ambiguity." ${ }^{34}$ However, I will leave that judgment to others.

(2) Vaughan asserts that the results-oriented jurisprudence which I allegedly espouse could, in the era of the Charter, produce a free-wheeling imperial judiciary imposing its perception of the "sociological realities" of Canada as an act of almost untrammelled freedom. I find this description of my position surprising. I explicitly

30 Vaughan, "Critics of the Judicial Committee," 505. It is difficult to come to grips with Vaughan's position without a more elaborate understanding of what he means by "the continued existence of Canada as one nation."

31 Cairns, "The Judicial Committee and its Critics," 334-38.

32 Evan Gray, "'The O'Connor Report' on the British North America Act, 1867," Canadian Bar Review 17 (1939), 334, cited in Cairns, "The Judicial Committee and its Critics," 337, n. 148.

33 K. N. Llewellyn, "The Constitution as an Institution," Columbia Law' Review 23 (1934), 33, cited in Cairns, "The Judicial Committee and its Critics," 335, n. 140.

34 Vaughan, "Critics of the Judicial Committee," 502. 
argued that a developed jurisprudence had to come to grips with the particular institutional division of labour characteristic of the Canadian polity. ${ }^{35}$. I continue to adhere to that position in the more complex division of labour which the Charter has brought in its wake. At a minimum, that division of labour imposes a particular style of reasoning on the judicial process, and requires attention to the non-elected status of judges and a recognition that certainty and predictability are more essential virtues for courts than for legislatures.

It is nevertheless evident that the Charter-even given s. 33-enhances the relative significance of courts vis-à-vis legislatures in the overall constitutional system. This is a commonplace of contemporary discussion. There is, however, an openness and indeterminacy to the emerging judicial role. The chief justice, on many occasions, has not only underlined the new responsibilities of the Supreme Court, but has explicitly asked for the assistance of social scientists as well as the legal fraternity in the working out of that expanded role. He does not view the Charter as speaking with a clarity which removes from the Court a range of discretion which can be wisely or foolishly handled. ${ }^{36}$

The Charter once more highlights the basic question of constitutional jurisprudence facing a final appeal court, how it should apply the discretion it unavoidably possesses. In an earlier era, that was the question facing the Judicial Committee. To describe the judicial task in terms of the controlled exercise of discretion is to deny that in constitutional adjudication the task of judging is equivalent to historical discovery. It is to affirm the leadership role which lurks in courtrooms and which recurrently surfaces in situations of novelty and uncertainty. Peter Russell has said it well: "One of the overriding interests of political scientists who study judicial review should be to discover where pure legal analysis ends and judgments of legislative policy and constitutional principle, which cannot themselves be determined by such analysis, begins." $3 i$

Professor Vaughan may believe that this rejoinder is based on a misunderstanding and misinterpretation of his position, as I think his article is of mine. Fortunately, neither of us has the power to decide who is right. These exchanges indicate that in this kind of subject-matter truth, our quarry, is approached but never captured.

35 Cairns, "The Judicial Committee and its Critics," 342-43.

36 For one example, see "An Address by the Right Honourable Brian Dickson, Closing Banquet, University of Ottawa Conference on the Supreme Court of Canada." October 4, 1985 (mimeo). See also the very impressive David B. Goodman Memorial Lectures delivered by Madame Justice Bertha Wilson at the University of Toronto. November 26-27, 1985 (mimeo), which subtly discusses four "tensions" in judicial decision-making, and in the second lecture explicitly addresses the judicial role with respect to the Charter.

37 Russell, Leading Constitutional Decisions. 17. 